\title{
Application of Inorganic and Organic Manure Fertilizers as Means of Conserving Plectranthus esculentus N.E.Br in Mid-Altitude Zone of Rwanda
}

\author{
Munyaneza Emmanuel1, Hategekimana J. Damascene², Ruffo K. Christopher3, \\ Minani Vedaste ${ }^{4}$ \\ ${ }^{1}$ Institute of National Museums of Rwanda, Kigali, Rwanda \\ ${ }^{2}$ University of Rwanda, Butare, Rwanda \\ ${ }^{3}$ Tanzania Tree Seeds Agency, Morogoro, Tanzania \\ ${ }^{4}$ National Agriculture and Export Development Board, Kigali, Rwanda \\ Email: munyaneza4@gmail.com, hategeka1@gmail.com, ruffock@yahoo.com, minaved2005@yahoo.fr
}

Received 15 December 2015; accepted 19 January 2016; published 22 January 2016

Copyright (C) 2016 by authors and Scientific Research Publishing Inc.

This work is licensed under the Creative Commons Attribution International License (CC BY).

http://creativecommons.org/licenses/by/4.0/

(c) (i) Open Access

\begin{abstract}
Plectranthus esculentus N.E.Br, locally known as "Impombo" is an important indigenous food crop in Rwanda which is currently endangered. One major factor that causes disappearance of this species, is the lower agronomic recommendations developed for growers and lack of information about nutrients contents leading to loss of interest in its cultivation. The objective of this study was to evaluate the response of living stone potato to inorganic manure fertilizers as an attempt to conserve and evaluate the potential of the crop food security crop, source of income, and its adaptation in the mid-altitude zone of Rwanda. The performance of the crop was evaluated under application of NPK (17:17:17) and farm yard manure fertilisers. These fertilizers were evaluated using a Randomized Completely Block Design (RCBD) with three replications. Analyse of variance showed that significant at $(p<0.01)$ was recorded in stem height, number of leaves but not high in stem diameter. The results indicated that vegetative growth and yield of plants in control plots were lower than what was obtained in treated plots. Production of living stone potato on large under application NPK (17.17.17) and organic fertlizer will ensure the conservation of genetic resources, food security, agricultural development and financial benefit to local farmers.
\end{abstract}

\section{Keywords}

Livingstone Potato, Natural Heritage Conservation, Food Security, Fertilizer, Vegetative Parameters, Reproductive Parameters 


\section{Introduction}

Plectrathus esculentus N.E.Br is a perennial herb belonging to Lamiaceae family (Figure 1). The plant is commonly known as Kaffir potato or Livingstone potato in English; while in Kinyarwanda it is called Impombo or Inderabageni and Inumbu in Kirundi. Since Livingstone potato is in a blink of extinction, it is now rare and unknown in many part of Rwanda. This species is only being cultivated as a minor root crop by very few farmers (about six) on less than $600 \mathrm{~m}^{2}$ (0.6 ha) in Nyamagabe district. This important indigenous food crop is now on verge of disappearing hence, its conservation may be a good contribution for natural heritage conservation. The Livingstone potato is an essential food crop and important source of income to small scale farmers. The tubers are boiled with beans or rice main meal, while the leaves are cooked as vegetable [1].

Nutritionally, the tuber is a good source of carbohydrates (29.32 - $85.40 \mathrm{~g} / 100 \mathrm{~g})$, rich in protein (10.52 g/100g) and minerals particularly Sodium (8 - $21.8 \mathrm{mg} / 100 \mathrm{~g})$, Calcium (55 - $90 \mathrm{mg} / 100 \mathrm{~g})$, Potassium (12.25 - 15 $\mathrm{mg} / 100 \mathrm{~g})$, Iron (100 - $155 \mathrm{mg} / 100 \mathrm{~g}$ ) and Magnesium (15.5 - $64.8 \mathrm{mg} / 100 \mathrm{~g})$ [2]-[5].

Apart from nutritional importance, the Livingstone potato is also reported to have medical values, hence the name Inderabageni in Kinyarwanda. This name originated from its values of not producing fat when cooked with beans, thus being respectful food for brides. According to Akueshi [3] and Kyesmu [6], the leaves of Plectrathus esculentus are strongly aromatic and very bitter, but have medicinal uses in certain areas of Africa. For example, decoction is taken in the Ubangi area of Democratic Republic of Congo (DRC) for treating taenia (human tapeworm), and a bolus of crushed leaf is used as a suppository for oxyuris (human thread worm) [7].

Although Livingstone potato has many nutritional, social and economic values, yet no research has ever been done on its production, uses and development in Rwanda or in other Eastern African cultures. It is only being cultivated by old farmers for their own interest and is never reported by any extension workers or local leaders at village. Recently, however, some efforts to initiate its research along with other minor root crops have started in Nigeria and outside Africa with purpose of establishing their potentials [5]. An initial result on agronomic studies in Nigeria indicated that the yield of Plectranthus esculentus ranged from 2 to 6 tons/ha [8]-[11]; when 400 $\mathrm{kg} \cdot \mathrm{ha}^{-1}$ of NPK 15:15:15 was applied with planting density of 40,000 plants $\cdot \mathrm{ha}^{-1}$.

In central Africa, the Livingstone potato is estimated to give a larger yield than any other genera of Lamiaceae family in a range of (13 to 25 tons)/ha [7] [12], and could be increased under improved husbandry. In South Africa, the crop has a yield potential above 60 t/ha under good growing conditions [11]. Therefore, it is important to conduct intensive study to rescue the crop and use it for food security, medicine and income generation for benefit to producers.
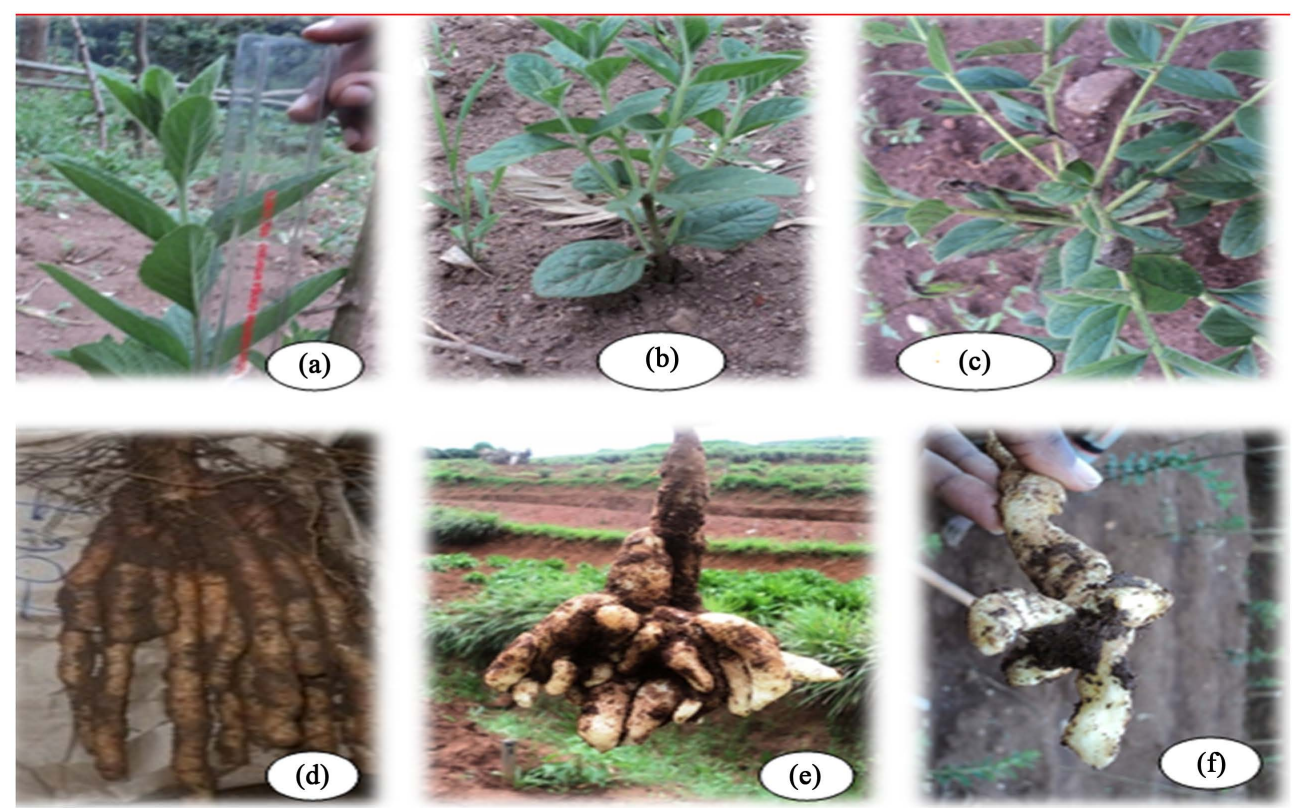

Figure 1. (a)-(c) Vegetative characteristics of Livingstone potato; (d)-(f) Reproductive characteristics of Livingstone potato. 


\section{Methodology}

\subsection{Experimental Site Description}

The experiment was established at Ruhande experimental station of the National University of Rwanda, located in Ngoma sector of Huye District in the Southern Province of Rwanda. The site is located at about $1200 \mathrm{~m}$ from the UR Faculty of Agriculture. The station is situated in the mid-altitude zone at $1714 \mathrm{~m}$ above sea level. The geographic coordinates of the site are $29^{\circ} 44^{\prime} 37.3^{\prime \prime}$ East' longitude and $2^{\circ} 36^{\prime} 41.6^{\prime \prime}$ latitude South at a slope of $26 \%$. Ruhande station has rainfall distribution pattern of $1200 \mathrm{~mm}$ and an average temperature of $19^{\circ} \mathrm{C}$, (MINALOC, 2011) [13].

\subsection{Field Management}

The field management was established at Ruhande research station during the agricultural season A, that starts in September and ends with February of the following year, since 2011. This is the good cropping season for Plectranthus esculentus, according to the farmers. Land was tilled using hoes in order to facilitate germination, growth and weeding. Planting was done one day after land preparation. The planting materials were cuttings of tubers with the size of 2 - $4 \mathrm{~cm}$ of length. The tubers were collected from Nyamagabe district, from local farmer who grew the crop many years ago. Inorganic fertilizer, NPK $(17: 17: 17)$ and organic manure were applied at the rate of $300 \mathrm{~kg} / \mathrm{ha} /$ year and $6000 \mathrm{~kg} / \mathrm{ha} /$ year were used. Urea was top-dressed for the plots which were applied inorganic fertilizers, after first weeding at rate of $150 \mathrm{~kg} / \mathrm{ha}$.

\subsection{Analysis of Soil Sampled}

Soil samples were collected from nine plots between 0 - $30 \mathrm{~cm}$ deep using soil auger. The soil texture was analyzed using the Bouyoucos or Hydrometer method as described by Okalebo et al. [14]. Soil pH was measured by introducing electrodes of $\mathrm{pH}$-meter into the suspension of soil-water, and then $\mathrm{pH}$ was recorded. Soil organic carbon was determined using the modified method consisting of the organic matter oxidation by potassium, as described by Walkley and Black [15]. The amount of exchangeable cations was determined by atomic absorption spectrophotometer [14]. Available phosphorus was determined using Olsen method [16].

\subsection{Experimental Design}

The plot size was $2 \times 5 \mathrm{~m}$ with each Plot having a population of 33 plants, at a spacing of $50 \mathrm{~cm}$ between rows and $40 \mathrm{~cm}$ within rows. This gave a total population of 3300 plants/ha. The (tubers) were planted at $8 \mathrm{~cm}$ deep with one tuber in each hole. The total area under experimental study was $90 \mathrm{~m}^{2}$ with 297 plants (tubers). The treatments were treated in the field by using a Randomized Completely Block Design (RCBD) with three replications

Treatments were:

1) T1: control: no fertilizer.

2) T2: NPK (17-17-17) at 300 kg/ha (rate recommended by Rwanda Agriculture Board for Irish potatoes).

3) T3: organic manure (farm yard manure: animal west) at $6000 \mathrm{~kg} / \mathrm{ha}$ (rate recommended by Rwanda Agriculture Board for Irish potatoes).

\subsection{Data Collection}

Plant height $(\mathrm{cm})$ was determined using a standard ruler by measuring the heights of three representative plants of Livingstone potatoes taken by net selection in every plot from the ground level to the upper level of the plants. The number of leaves was recorded by counting the number of leaves on thee representatives Livingstone potato plants selected in each plot. Stem diameter was measured using a micro caliper (cm).

Harvesting of tubers was done after 200 days of planting the tuber. The reproductive measurements taken by net selection in each plot were: weight, number, length and diameter of tubers. Weight of tubers was determined by weighing three Livingstone potato tubers of Livingstone potatoes taken by net selection from each plot using electronic balance. Length of tubers $(\mathrm{cm})$ was determined by measuring three representative tubers of Livingstone potatoes taken by measuring from plot. Diameter of tubers was determined by measuring diameters of three representative tubers of Livingstone potatoes taken by net selection in every plot, using a micro caliper (cm). 


\subsection{Statistical Analysis}

Data were analyzed using analysis of variance with Genstat Discovery 4th Edition Software (VSN International Ltd, 2011). Significant differences in means were separated using Least Significant Difference (LSD at 5\% level of probability).

\section{Results and Discussion}

The results obtained from this study showed that application of N.P.K (17:17:17) $300 \mathrm{~kg} / \mathrm{ha}$ and farm yard manure gave the best yield and growth than the control. Similarly, Allemann and Coertze [11] reported that using fertilizers increases yield of Livingstone potato under good growing conditions. The data from this study showed that fertilizer application significantly affected the growth habit and yield of Livingstone potato. The plots without fertilizer application, show poor growth habit and gave low yield (Table 1 and Table 2). The pH which was 5.22, influenced the good growth and yield, differently however Burkill [7] reported that the value of $\mathrm{pH}$ required for growing Livingstone potato was 6.5 to 7 . With the reference to USDA Soil textural triangle, the physical properties showed that the soil was a sandy clay loam (Table 3).

Application of NPK significantly increased stem height, diameter, leaves number and yield of Livingstone potato. The results showed that, the conservation of planting materials is possible when the crop is cultivated under good growing conditions. The results of vegetative measurements showed that Livingstone potato can attained $98 \mathrm{~cm}$ of height with up to 64 leaves and a stem diameter of $1.06 \mathrm{~cm}$ when grown under a favourable soil condition and using fertilizer. Similarly, Tredgold [17] and Schippers [18] reported that the shrub grows to approximately $0.6 \mathrm{~m}$ to about $2 \mathrm{~m}$ in height when the crop is grown under good growth conditions. In this study, the Livingstone potato was propagated using vegetative parts, the edible parts- the tubers instead of using seeds. The vegetative parts of the crop can produce many branches if cut early, about 60 days after germination. This practice can also increase the vigor of the crop; and probably increases the yield.

Table 1. Responses of growth parameters of livingistone potatato to NPK fertilizer and organic manure at Ruhande, Rwanda in 2011 and 2012 cropping seasons.

\begin{tabular}{cccccccccc}
\hline Fertilizer & PHT60 $^{+=}$ & PHT120 $^{+=}$ & PHT200 $^{+=}$ & No.L $60^{+=}$ & No.L $120^{+=}$ & No.L $200^{+=}$ & D.st $60^{+=}$ & D.st $120^{+=}$ & D.st $200^{+=}$ \\
\hline Control & 24.7 & 38.7 & 52.70 & 12.30 & 26.90 & 34.067 & 0.940 & 1.190 & 1.190 \\
Manure & 30.1 & 52.0 & 70.97 & 14.63 & 35.67 & 56.867 & 0.990 & 1.193 & 1.193 \\
NPK & 37.9 & 68.8 & 98.4 & 14.93 & 43.03 & 64.267 & 0.987 & 1.033 & 1.067 \\
$\begin{array}{c}\text { LSD } \\
\text { (at 5\% level) }\end{array}$ & 2.004 & 0.911 & 1.074 & 0.886 & 1.171 & 0.3463 & 0.1350 & 0.0684 & 0.0763 \\
CV\% & 3.6 & 0.8 & 0.6 & 2.8 & 1.5 & 0.3 & 8.6 & 2.7 & 2.9 \\
\hline
\end{tabular}

Values are means of three replicates. ${ }^{+=}$: indicates days after fertilizer application. PHT: Plant height. No.L: Number of leaves; D.st: Diameter of stem.

Table 2. Responses in yield parameters of livingistone potato to NPK fertilizer and organic manure application at Ruhande, Rwanda in 2011 and 2012 cropping seasons.

\begin{tabular}{|c|c|c|c|c|c|}
\hline Fertilizer & D.Tub & H.Tub & No.Tub & Yld (g)/0.9m² & Yld (tons/ha) \\
\hline Control & 2.570 & 23.23 & 24.00 & 526 & 5.8 \\
\hline Manure & 2.737 & 27.27 & 41.67 & 866 & 9.6 \\
\hline NPK & 2.833 & 30.03 & 49.67 & 1645 & 18.3 \\
\hline Fpr. & $0.020^{*}$ & $0.003^{*}$ & $<0.001^{* *}$ & $<0.001^{* *}$ & $<0.001^{* *}$ \\
\hline LSD (at 5\% level) & 0.1507 & 2.3 & 4.207 & 205.9 & 205.9 \\
\hline $\mathrm{CV} \%$ & 2.4 & 3.8 & 4.8 & 9.0 & 9.0 \\
\hline
\end{tabular}

D. Tub: Diameterof tuber; H.Tub: Height of tuber; No.Tub: Number of tubers per plant; Yld: Yield. 
Table 3. Chemical and physical properties of the soil of the field experiment at Ruhande Station during 2011-2012.

\begin{tabular}{ccc}
\hline No. & Soil properties & Value \\
\hline $\mathbf{1}$ & PH $\left(\mathrm{H}_{2} \mathrm{O}\right)$ & 5.22 \\
$\mathbf{2}$ & Organic Carbon $(\mathrm{g} / \mathrm{kg})$ & 2.93 \\
$\mathbf{3}$ & Total Nitrogen $(\%)$ & 0.92 \\
$\mathbf{4}$ & Available P $(\mathrm{mg} / \mathrm{kg})$ & 0.44 \\
$\mathbf{5}$ & Exchangeable Ca $(\mathrm{Cmol} / \mathrm{kg})$ & 2.03 \\
$\mathbf{6}$ & Exchangeable Mg $(\mathrm{Cmol} / \mathrm{kg})$ & 0.59 \\
$\mathbf{7}$ & Exchangeable K $(\mathrm{Cmol} / \mathrm{kg})$ & 0.44 \\
$\mathbf{8}$ & Exchangeable Na $(\mathrm{Cmol} / \mathrm{kg})$ & 0.22 \\
$\mathbf{9}$ & Sand & $53 \%$ \\
$\mathbf{1 0}$ & Silt & $28 \%$ \\
\hline
\end{tabular}

The results showed that NPK 17:17:17 at application rate of $300 \mathrm{~kg} /$ ha gave the yield of 18.3 tons/ha and increase yield by $54.5 \%$ compare the total yield obtained in this study. The results also showed that organic manure gave a tuber yield of 9.8 tons/ha at the rate of $600 \mathrm{~kg} / \mathrm{ha}$ and increased the yield by $28.5 \%$ compare the total yield obtained in this study. Control plots gave a tuber yield of 5.8 tons/ha and increased yield by $17 \%$ compare the total yield obtained in this study.

\section{Recommendations}

The authors of this paper would like to recommendation that:

1) A survey of Livingstone potato varieties found in Rwanda is necessary for comparison on their performance.

2) A study on propagation in vitro should be done for getting healthy and homogeneous planting materials of Livingstone potato.

3) The ministry of Agriculture should consider investing on conservation and development of genetic resources, for agricultural development for the benefit of the present and future generation of Rwanda.

4) The government of Rwanda has to introduce a program of domesticating and promoting indigenous food crops in Rwanda.

5) The Ministry of health should explore nutritional and medicinal value of Livingstone potato for their potential contents of mineral, vitamins, carbohydrates and proteins.

\section{Conclusion}

Application of NPK 17:17:17 at rate of $300 \mathrm{~kg} / \mathrm{ha}$ and organic manure at rate of 6000/ha were maximized the growth, productivity and this would ensure the conservation of Livingstone potato in the mid-altitude zone of Rwanda. It was concluded also, fertilizer application increased height of stem, number of leaves, and stem diameter of Livingstone potato. NPK 17:17:17 has significantly increased growth and yield of Livingstone potato than organic manure. Little or no attention has been given to this crop with the resulting in no agronomic recommendations being developed for growers, this general lack of information has led to the loss of interest in its cultivation and, consequently, a gradual loss of germplasm.

\section{Acknowledgements}

The authors would like to thank the Institute of National Museums of Rwanda, University of Rwanda and the National Industrial Research and Development Agency, for providing logistical support as well as technical support from any source like technicians or data analysis experts. 


\section{References}

[1] Demissie, A. (1997) Pontentially Valuable Crop Plant in Vavilovain Centre of Diversity: Ethiopia. In: Guirano, L., Ed., Proof a Conference on Crop Genetic Resources of Africa, Nairobi, August 1995, IPGRI, Rome.

[2] Gila, M.A. (1984) Morphogenetic Variation in Rizga Plectranthus esculentus N.E.br. http://www.zimbabweflora.co.zw/speciesdata/species.php?species_id=149820

[3] Akueshi, C.O. (1989) Nigerian J. Botany Chemistry of the Genus Plectranthus.

[4] Temple, V.J. (1991) Chemical Composition of Livingstone Potato Tubers (Plectranthus esculentus). Journal of the Science of Food and Agriculture, 56, 215-217. http://onlinelibrary.wiley.com/doi/10.1002/jsfa.2740560210/abstract

[5] Olojede, A.O.C.C., Nwokoch, O.N., Eke-Okoro and Emehute, J.K.U. (2004) Varietal Response of Livingstone Potato (Plectranthus esculentus N.E.Bar) to NPK Fertilizer Application at Umudike NRCRI Annual Report, 84-87.

[6] Kyesmu, P.M. (1989) Plectranthus esculentus N.E.Br a Minor Tuber Crop in Dire Need of Rescue from Extinction. Lamiales Newsletters, 3, 3-5.

[7] Burkill, H.M. (1995) The Useful Plants of West Tropical African. Vol. 3, Families J-L., Royal Botanic Gardens, Kew.

[8] Tindall, H.D. (1983) Vegetables in the Tropics. The Macmillan Press Ltd., 243-245. http://dx.doi.org/10.1007/978-1-349-17223-8

[9] Roecklein, J.C. and Leung, P.S. (1987) A Profile of Economic Plants. Transaction Books, New Brunswick. http://ecoport.org/ep?Plant

[10] Alleman, J. (1996) Two Indigenous Tuber Species Being Evaluated as Possible Food Crops. ARC Roodeplaat Vegetable and Ornamental Plant Institute, Pretoria.

[11] Allemman, J. and Coertze, A.F. (1996) Plectranthus. http://ecoport.org/ep?Plant=8753\&entityTypePLCR**\&entityDisplayCategory=full

[12] Daiziel, J.M. (1937) The Useful Plants of West Tropical Africa 7-267 Papilionoideae, 267-483.

[13] Minaloc (2011) District Potentialities Assessment for the Integrated and Self-Cantered Local Economic Development. Final Report, Ministry of Local Government, Kigali.

[14] Okalebo, J.R., Gathua, W.K. and Woomer, L.P. (2002) Laboratory Methods of Soil Plant Analysis: Working Manual. 2nd Edition, 28-29, 42, 58, 61.

[15] Waikley, A. and Black, I.A. (1994) Determination of Organic Matter in the Soil by Chromic Papillionoidege, 267-483.

[16] Olsen, S.R., Cole, C.V., Watanabe, F.S. and Dean, L.A. (1954) Estimation of Available Phosphorous in Soil by Extraction with Sodium Bicarbonate. USDA Circular, 939.

[17] Tredgold, M.H. (1984) Food Plants of Zimbabwe. http://ecoport.org/ep?Plant.E-Resources

[18] Schippers, R.R. (2000) African Indigenous Vegetables: An Overview of the Cultivated Species. Natural Resources Institute/PCP EU Technical Centre for Agricultural and Rural Cooperation. 